\section{IUGS Science Excellence Awards 2012}

The IUGS Science Excellence Awards were created by the IUGS Executive Committee in 2011 to recognize outstanding original contributions or achievements that mark a major advance to the Earth Sciences. Candidates to this Award are nominated by the IUGS Commissions for outstanding scientists within their respective field of competence.

The first Science Excellence Awards were presented at the 34th International Geological Congress, Brisbane, on August $6^{\text {th }}, 2012$ in the following disciplines: Environmental Geology, Geological Education, Geoscience information, History of Geology Award, Stratigraphy Award and Structural Geology.

\section{Environmental Geology}

Professor Ibrahim bin Komo, University of Malaysia, Malaysia.

Professor Ibrahim Komoo received his Bachelors degree from Universiti Kebangsaan Malaysia, and a doctorate in Engineering Geology from the University of Strathclyde. In 1984 he became head of the Department of Geology at Universiti Kebangsaan and then Senior Manager of the Petronas Research Institute. He became Associate Director of the Institute for Environment and Development (LESTARI), at the Universiti Kebangsaan, rising to Deputy Director and then Director. Under his leadership LESTARI developed a diverse team to address multidisciplinary approaches to geo-environmental with links to ecologists, economists and public communicators, and became increasingly influential in guiding environmental policies in Malaysia and assisting inputs to international discussions on matters such as adaptation to climate change and sustainable development. He served as Deputy ViceChancellor for Research and Innovation at Universiti Kebangsaan and had visiting appointments at Universities in Kyoto and Vienna. He has been an invited speaker in many places.

Professor Ibrahim is a Fellow of the Institute of Geology and a Council Member of the Academy of Sciences in Malaysia. He served as President of the Geological Society of Malaysia and Vice-President of the Institute of Geology, Vice-president of IAEG and on the Editorial Board of its Bulletin, and President of the IAEG Malaysian chapter since 1996 onwards. He developed a strong interest in geosciences in nature conservation and has chaired the Malaysian Geo-heritage Group, is a Member of the National Heritage Council, and head of its Environment and Natural Resources Cluster, as well as an expert to the UNESCO Geoparks initiative. Prof. Ibrahim was instrumental in getting Langkawi Island recognised as the first Geopark in Southeast Asia.

His work has embraced engineering geology, geohazard management, environmental geology, nature conservation, and Earth systems science for sustainable development. His efforts were recognised by the award of the title of Dato' Setia Negeri Sembilan and the Langkawi Award, the highest award for environmental conservation in Malaysia. He is now Vice Chancellor at the University of Malaysia Terenggannu. The IUGS Commission for Geoscience in Environmental Management has been particularly grateful for his support for meetings and for our former Chairperson.

- Citation by Brian Marker

\section{Geological Education}

Professor Nir Orion, Weizmann Institute of Science, Israel.

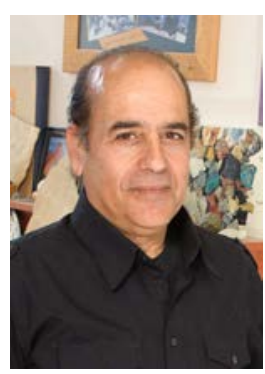

Nir Orion has shown a lifetime of commitment to Earth science education which is unlikely ever to be exceeded. He has pioneered and led the teaching of Earth science in schools in his native country of Israel over many years, persevering though setbacks and disappointments to transform the way in which Earth science education is taught and perceived.

But Nir has done much more than this. It was his idea in the late 1990s to form an international group to support the teaching of Earth science globally and he led the working group which eventually became the International Geoscience Education Organisation (IGEO). Since that time the IGEO has run a number of international conferences and coordinated education themes at different International Geological Congresses, with the particular aim of bringing delegates from developing countries to take part in these important meetings. Nir has strongly supported the development of the International Earth Science Olympiad (IESO), which is now in its sixth year.

Nir's research work into geoscience education is well known internationally and has resulted in a wide range of publications, many with his research students. Through this work he has moved forward our understanding of the teaching of geological time, spatial visualisation in geoscience, earth systems science, the thinking skills involved in geological education and outdoor education. Nir has supervised more than ten graduate students undertaking Masters and PhDs in recent years and his leadership has supported their important contributions to geoscience education. Recently, with Charles Ault, he compiled an important review of geoscience educational research, published in the Handbook of Research on Science Teaching and Learning, edited by Abell and Lederman.

Nir is currently Head of the Earth and Environmental Sciences group and Chair of the teaching committee in the Department of Science Teaching at the Weizmann Institute of Science in Israel. In 2001 he was awarded the Israeli Geological Society Medal for contributions to society through Earth science education. Currently he is also a leading member of the international research group of Deep Time Perception. He continues to strongly support global geoscience education through his work in Israel and internationally, and he is therefore a most worthy recipient of this recognition.

- Citation by Chris King

\section{Geoscience Information}

Dr. John L. Laxton, British Geological Survey, United Kingdom

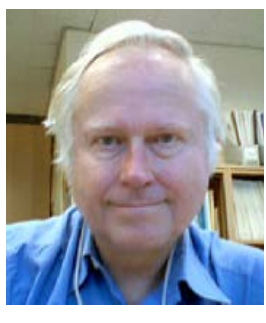

John Laxton has worked in the field of geological computing for almost 30 years - virtually since the inception of the discipline.

He began work at the British Geological Survey applying early spatial computing and GIS to mineral assessment data and moved on to applied geological mapping in urban areas of the UK. He always brings a focused and rational approach to these novel challenges. 
His involvement in geoscience computing continued through the 1990s and he was a key member of the BGS team which designed the first ever digital geological map database for the UK, demonstrating the absolute necessity for standards and consistency.

His extensive experience in the ensuing decades has been applied to both European and global issues.

John was technical manager for the EU ESPRIT funded GEIXS project which created a harmonised metadatabase of geoscience data for Europe, and worked on several international development projects aimed at assisting the Geological Surveys of developing countries to make the most effective use of their data holdings by drawing on modern IT based technologies.

In 2003 he was appointed coordinator to the Interoperability Working Group (IWG) of the IUGS Commission for the Management and Application of Geoscience Informationn (CGI). Since then, this group has drawn on international expertise to develop a geoscience interchange language (GeoSci ML). Work on GeoSciML has continued since, with the scope and design being improved, and increased implementation globally.

He worked on the informatics specification, data model, interoperability and standards for the EU eContentPlus project "OneGeology-Europe“ which aimed to demonstrate an implementation of GeoSciML in delivering distributed data for a geological map of Europe portal.

Recently he has been the editor of the INSPIRE Geology and Mineral Resources Technical Working Group, which has drawn on his experience with GeoSciML and the application of spatial standards to produce the geosciences information delivery specification for Europe.

His long experience and objective approach is combined with a quiet but determined manner. We congratulate him on an outstanding contribution to international geoscience informatics!

\section{- Citation by Kristine Asch}

\section{Vladimir V. Tikhomirov History of Geology Award}

Professor Emeritus Hugh S. Torrens, University of Keele, United Kingdom

Professor Hugh Torrens is one of those rare geologists who has bridged the divide between science and the humanities and made a huge contribution to the studies of the history of the geological thought.

Over most of his career Hugh has been based at the University of Keele in the United Kingdom where he remains today as Emeritus Professor. He has a BA, with a geology major, from Oxford University and a $\mathrm{PhD}$ in Jurassic stratigraphy from the University of Leicester.

After initial contributions in stratigraphy, Hugh's life work has been devoted to studies in the history of geology and related fields. He has become the world authority on the work of William Smith.

In his adopted field Hugh is author of some 345 books, papers, and reviews. Notably his 47 articles for the Oxford Dictionary of National Biography constituted more than enough material for a major book. Hugh also had a collection of his major papers published as a 'variorum' book in 2002, entitled The Practice of British Geology 1750-1850.

Hugh's contribution has extended to numerous historical organisations, in which he has served with distinction, including:

Chairman of Geological Curators'

Group of the Geological Society of London (1976-1980)

President of the British Society for the History of Science (1990-1992) Councillor of the History of Earth Sciences Society (1996-1998)

Conseiller étranger of the Comité Français d'Histoire de la Géologie (1991-1992)

Hugh has also long been a member of the INHIGEO, and a strong supporter of the Commission's activities. He is notable for the immense amount of assistance he willingly gives to younger scholars and to colleagues in need of information, of which he seemingly has an infinite supply.

Hugh also served as INHIGEO President in the years 1996-2000 and has since been recognised as an Honorary Senior Member of INHIGEO.

It is, then, with great pleasure that IUGS honours today Professor Hugh Torrens as the worthy inaugural recipient of the V. V. Tikhomirov History of Geology Award.

- Citation by Silvia Figuerôa

\section{Digby McLaren Stratigraphy Award}

\section{Professor Stig M. Bergström, Ohio State} University, U.S.A.

Prof. Bergström's scientific contributions have been immense and have evolved through

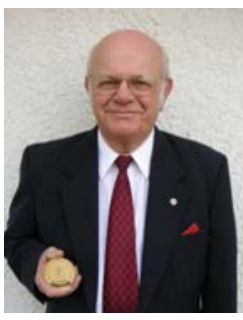

his career, which can be summarized as follows: specialist on Ordovician conodonts, then Ordovician biostratigraphy worldwide, and conodont paleobiogeography and paleoeco-

logy; with Walt Sweet firmly established multi-element taxonomy for conodonts; integrated graptolite and conodont biostratigraphies for the Ordovician; long-time voting member and officer of ICS Subcommission on Ordovician Stratigraphy, led group that established links between major bentonite successions in Ordovician-Silurian successions of eastern-midwestern North America, Scandinavia, and Argentine Precordillera; contributed significantly to establishment of carbon isotope stratigraphy for much of Ordovician.

Prof. Bergström has advised and supervised a large number of students who have had successful careers as biostratigraphers; he has worked with a number of post-doctoral fellows who were young conodont specialists from outside the United States; and he has collaborated extensively for decades with Chinese colleagues.

Prof. Bergström was a long-time voting member of the Ordovician Subcommission and served for eight years as its Secretary. He organized an International Symposium on the Ordovician System in 1978. And, he was a (the) major contributor to the development of the single set of global chronostratigraphic units defined by GSSPs for the Ordovician System.

- Citation by Stanley C. Finney

\section{Structural Geology}

Professor Emeritus John G. Ramsay, University of Zürich. Switzerland.

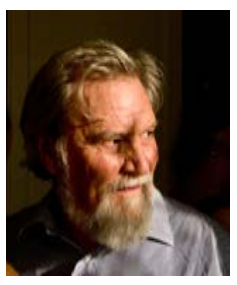

John Ramsay has contributed more to our understanding of the geometry of deformed rocks than any other person in the past 100 years. His contribution focuses essentially on the distribution of strain in deformed rocks and is distinguished by an emphasis on careful observation of field examples ranging from the hand specimen to regional mappable structures rather than being model based with a reliance on theoretical postulates or concepts derived 
from other fields such as material science. In particular he is one of the first to widely apply finite strain theory to rock deformation and to develop ways of estimating such strains. His work shows an uncanny insight and "feel" for the strain fields that are possible in rocks deformed by structures such as folding and boudinage and people who study the mechanical theory of folding would be wise to take his observations into account. This approach differs from but forms a strong foundation for subsequent developments by others that concentrate on the kinematics of deformation. His contribution extends to a detailed analysis of the geometry of single folds, the geometry that develops due to the interference of more than one set of folds, and the geometrical patterns developed during the deformation of early linear structures. His studies have helped elucidate the structural history of both the Scottish Highlands and the European Alps. An important part of his legacy will be the very large number of high quality students from Imperial College, London and the ETH in Zurich that have progressed to teach and enhance the subject of structural geology all over the world. His contributions to Structural Geology make John Ramsay a worthy candidate for the award of an IUGS Science Excellence Award.

- Citation by Bruce Hobbs 